\title{
WAHANA HIJAU
}

Model Pengembangan Ekonomi Lokal (PEL) Berbasis Produktivitas Kopi Arabika Spesialti di Kabupaten Simalungun

JefRudiantho Saragih

Pembangunan Kawasan Ekonomi Indonesia-Malaysia

Muchtar Ahmad

Analisis Icor dan Kaitannya Terhadap Pertumbuhan Ekonomi di Provinsi Sumatera Utara

Rahmanta

Analisis Pengembangan Mekanisme Penerimaan Hibah Luar Negeri terhadap Peningkatan Efektivitas Pengelolaan Hibah Luar Negeri Sektor Pendidikan Tahun 2006-2011

Teguh Murdjijanto dan Hania Rahma

Pengukuran Kinerja Pengelolaan Keuangan Pemerintah Daerah di Kabupaten Batu Bara

Joy Land Defarci, Erlina, dan Rudjiman

Desentralisasi Fiskal Kaitannya dengan Pertumbuhan Ekonomi Dan Disparitas Wilayah Kota Gunungsitoli

Yasokhi Tertulianus Harefa, Erlina, dan Kasyful Mahalli 


\section{WAHANA HIJAU \\ Jurnal Perencanaan \& Pengembangan Wilayah \\ ISSN 1858-4004 \\ Volume 7, Nomor 3, April 2012}

\section{DAFTAR ISI}

Model Pengembangan Ekonomi Lokal (PEL) Berbasis Produktivitas Kopi Arabika Spesialti di Kabupaten Simalungun

Jef Rudiantho Saragih

Hal. $117-125$

Pembangunan Kawasan Ekonomi Indonesia-Malaysia

Muchtar Ahmad

Hal. $126-138$

Analisis Icor dan Kaitannya Terhadap Pertumbuhan Ekonomi di Provinsi Sumatera Utara

Rahmanta

Hal. $139-146$

Analisis Pengembangan Mekanisme Penerimaan Hibah Luar Negeri terhadap Peningkatan Efektivitas Pengelolaan Hibah Luar Negeri Sektor Pendidikan Tahun 2006 - 2011

Teguh Murdjijanto dan Hania Rahma

Hal. $147-162$

Pengukuran Kinerja Pengelolaan Keuangan Pemerintah Daerah di Kabupaten Batu Bara

Joy Land Defarci, Erlina, dan Rudjiman

Hal. $163-176$

Desentralisasi Fiskal Kaitannya dengan Pertumbuhan Ekonomi Dan Disparitas Wilayah Kota Gunungsitoli

Yasokhi Tertulianus Harefa, Erlina, dan Kasyful Mahalli

Hal. $177-190$ 


\title{
MODEL PENGEMBANGAN EKONOMI LOKAL (PEL) BERBASIS PRODUKTIVITAS KOPI ARABIKA SPESIALTI DI KABUPATEN SIMALUNGUN
}

\author{
Jef Rudiantho Saragih \\ Dosen Agribisnis Fakultas Pertanian Universitas Simalungun \\ jef_saragih@usi.ac.id
}

\begin{abstract}
Specialty arabica coffee productivity could be improved by land extensification, optimizing the use of family labor, increase cost of organic and chemicals fertilizer, land use (intercropping and/or multistrata), increase in the price of parchment, increase in premium coffee prices, increase in liquidity of financial of household farmer, and increase in the practice of coffee pruning, and control of coffee berry borer (CBB). The application of good agriculture practices (GAPs) can increase the quality of the coffee produced in the Simalungun highlands. Increased productivity and quality is very prospective in the LED based on specialty coffee, mainly farmers net income and local employment indicator. As the acceleration factors to increase productivity and quality of specialty arabica coffee is necessary: (1) re-mapping the areas of unique production, including the revision of Kepmenhut 44/2005; and (2) introduce and implementation of selected development programs at the farm and regional level. Specialty arabica coffee contributed by $3.27 \%$; 5.99\%; and $13.17 \%$ in regional income of Simalungun District, agriculture sector, and estate crop subsector, respectively. Base on indicators of absorption of local labor, specialty arabica coffee is able to contribute about $8.29 \%, 14,47 \%$; and $24,86 \%$ in the total workforce, agriculture sector, and estates crop subsector. Specialty arabica coffee farm able to give an US\$2.05 per capita per day, so it is able to reduce of poverty level in rural region. It is recommended that the Simalungun local government to adopt the model of LED specialty arabica coffee commodity-based.
\end{abstract}

Keywords: Productivity, land use, LED

\section{PENDAHULUAN}

Secara umum, kebijakan pembangunan wilayah dapat dibagi menjadi tiga: kebijakan pembangunan dari atas (top-down policy), kebijakan pembangunan dari bawah (bottomup policy), dan kebijakan pengembangan ekonomi lokal (PEL) atau local economic development (LED). PEL dinilai sebagai alternatif akibat berbagai kelemahan dua pendekatan pembangunan sebelumnya. Kebijakan pembangunan dari atas dapat menyebabkan disparitas antar-wilayah akibat eksploitasi sumberdaya lokal. Sementara kebijakan dari bawah seringkali memiliki muatan yang baik tetapi lemah dalam implementasi sehingga bersifat utopia (Adji, 2011; Iqbal dan Anugerah, 2009; Supriyadi, 2007).

Bartik (2003) mendefinisikan PEL sebagai peningkatan dalam kapasitas ekonomi lokal untuk menciptakan kesejahteraan bagi penduduk lokal. ILO (2010) menyatakan PEL merupakan proses pembangunan partisipatif melalui kemitraan publik dan swasta, menggunakan sumberdaya lokal dan keunggulan kompetitif dengan tujuan menciptakan kesempatan kerja dan pertumbuhan ekonomi yang berkelanjutan. Adji (2011) mendefinisikan PEL sebagai usaha mengoptimalkan pemanfaatan sumberdaya lokal yang melibatkan pemerintah, dunia usaha, masyarakat lokal dan organisasi masyarakat madani untuk mengembangkan ekonomi pada suatu wilayah. Bank Dunia (2011) menggambarkan PEL sebagai proses dimana publik, bisnis, dan sektor non-pemerintah bekerja secara kolektif untuk menciptakan kondisi yang lebih baik bagi pertumbuhan ekonomi dan penciptaan lapangan kerja. 
PEL mengutamakan peningkatan kesempatan kerja dan pendapatan rumah tangga, pengurangan kemiskinan dan pengangguran (Chmura dan Orozobekov, 2009). Tujuan utama PEL adalah merangsang kesempatan kerja lokal pada sektor tertentu untuk meningkatkan kesejahteraan masyarakat, dengan menggunakan sumberdaya manusia, sumberdaya alam dan kelembagaan yang ada (Blakely, 1994). Joseph (2002) menawarkan prioritas PEL yaitu: prioritas penciptaan lapangan kerja dan pengurangan kemiskinan.

Produksi pertanian merupakan sumber penting pendapatan petani dan kesempatan kerja di negara sedang berkembang (Ibanez, 2010). Thirtle et al. (2001) menyimpulkan bahwa variabel produktivitas pertanian memiliki pengaruh yang signifikan terhadap pengurangan kemiskinan. Dengan kata lain, terdapat hubungan yang kuat antara produktivitas pertanian dan kemiskinan. Hal ini sejalan dengan tujuan PEL yaitu mengurangi kemiskinan (Rodriguez-Poso, 2001; Joseph, 2002; Alburquerque, 2004), meningkatkan pendapatan masyarakat (James et al., 2002) dan meningkatkan kesempatan kerja (ILO, 2010; Bank Dunia, 2010; Rustiadi et al., 2009; Chmura dan Orozobekov, 2009).

Istilah kopi spesialti (specialty coffee) -dari sisi terroir atau milieu-- pertama kali diperkenalkan tahun 1978 oleh Erna Knutsen pada konferensi kopi internasional di Francis. Konsepnya sangat sederhana: "iklim-mikro geografis khusus yang menghasilkan biji kopi dengan profil citarasa unik" (Rhinehart, 2009). Indonesia memiliki cukup banyak kopi spesialti yang sudah punya reputasi di pasar internasional seperti Java Coffee, Gayo Mountain Coffee, Mandheling Coffee, Lintong Coffee, Toraja/Kalosi Coffee. Dari sisi sertifikasi, kopi spesialti mengacu pada kopi yang memperoleh harga premium melalui program sertifikasi antara lain: Organic, Fairtrade, Utz Certified, Rainforest Alliance, C.A.F.É. Practices, Common Code for the Coffee Community (4C), Bird Friendly, dan Indikasi Geografis (Mawardi, 2008b)

Berdasarkan pemikiran tersebut dapat disimpulkan bahwa salah satu tujuan pengembangan ekonomi lokal dan perencanaan wilayah adalah peningkatan produktivitas wilayah. Peningkatan produk- tivitas dapat meningkatkan kesempatan kerja, kesempatan kerja dapat meningkatkan pendapatan, peningkatan pendapatan pada gilirannya dapat mengurangi tingkat kemiskinan dan meningkatkan kesejahteraan masyarakat. Atas dasar pemikiran tersebut, kajian PEL dalam penelitian ini difokuskan pada peran produktivitas kopi arabika spesialti dalam pendapatan dan penyerapan tenaga kerja lokal di tingkat usahatani.

Kopi merupakan komoditas ekspor terpenting kedua dalam perdagangan global, setelah minyak bumi (Gregory dan Featherstone, 2008; ICO, 2010; Amsalu dan Ludi, 2010). Pada tahun 2011, Indonesia merupakan produsen kopi utama ketiga di dunia setelah Brasil dan Vietnam, sementara pada posisi keempat adalah negara Kolombia. Keempat negara ini menghasilkan sekitar 56\% produksi kopi dunia (ICO, 2012). Di Indonesia, penghasil kopi arabika terbesar adalah provinsi Sumatera Utara (Ditjen Perkebunan (2012). Kopi arabika Sumatera Utara telah memiliki reputasi global dengan nama Mandheling Coffee dan Lintong Coffee. Pengembangan kopi arabika di Simalungun memberikan kontribusi di Sumatera Utara hingga dikenal sebagai wilayah penghasil utama kopi arabika spesialti di Indonesia.

Kopi Simalungun termasuk kelompok Mandheling Coffee (Mawardi, 2008b), dan Mandheling Coffee merupakan kopi spesialti (Mawardi, 2007; Mawardi, 2009; Wahyudi dan Misnawi, 2007). Tanaman kopi arabika Sigarar utang mulai ditanam secara meluas sejak 10-15 tahun yang lalu, namun produktivitas dan kualitas yang masih relatif rendah merupakan masalah utama yang memerlukan jawaban untuk menjadikan komoditas ini sebagai basis PEL.

Produktivitas kopi arabika di Kabupaten Simalungun masih relatif rendah, hanya sekitar $50-65 \%$ dari produksi potensialnya. Dengan demikian, terdapat gap antara produksi aktual dan produksi potensial sebesar $35-50 \%$. Hal sejalan dengan AMARTA (2010) yang mengidentifikasi masalah pengembangan kopi arabika di Simalungun, yaitu antara lain produktivitas dan kualitas produk yang rendah. Secara nasional, kendala komoditas kopi di Indonesia adalah produktivitas dan kualitas yang masih rendah (Ibrahim dan Zailani, 2010). 
Berdasarkan uraian di atas, permasalahan penelitian yang diajukan terkait dengan bagaimana upaya meningkatkan produktivitas dengan menggali pengaruh faktor sosial ekonomi dan ekologi. Selanjutnya, bagaimana produktivitas kopi arabika spesialti mendorong peningkatan pendapatan petani dan penyerapan tenaga kerja, sebagai indikator utama PEL. Sebagai faktor akselerasi PEL, penelitian ini mengintegrasikan kajian aspek tataguna lahan dan policy review terkait kopi arabika spesialti sebagai basis PEL di wilayah dataran tinggi Kabupaten Simalungun.

Tema kajian empiris terdahulu mengenai produktivitas kopi dikaitkan dengan aspek sosial ekonomi dan ekologi antara lain adalah: pengaruh faktor sosial ekonomi terhadap pendapatan petani kopi (Doutriaux et al., 2008); pengaruh faktor sosial ekonomi dan ekologi terhadap produksi buah kopi (Wollni dan Brümmer, 2009); pengaruh faktor sosial ekonomi terhadap pendapatan petani kopi (Poudel et al., 2010), efisiensi produksi kopi (Nchare, 2007), faktor ekologi dan kualitas dan produksi kopi (Bote dan Struik, 2011); investasi usahatani kopi (Mauro, 2010); dan pendapatan petani kopi sistem multistrata (Safa, 2005). Sementara kajian mengenai PEL dilakukan oleh Bartik (2003), James et al. (2002), Weisbrod et al. (2004), Chmura dan Orozobekov (2009), Blakely, 1994, Joseph (2002), Supriana dan Nasution (2010). Young dan Kachmarek (2000), dan Morgan (2010).

James et al. (2002) melakukan kajian tentang dampak PEL terhadap pertumbuhan kesempatan kerja. Weisbrod et al. (2004) antara lain menggunakan variabel kesempatan kerja dan tingkat pendapatan sebagai indikator untuk mengevaluasi strategi PEL. Kinerja PEL dapat dikaji dalam tiga tujuan yang saling berkaitan: (1) evaluasi kinerja ekonomi lokal existing, (2) mengidentifikasi sasaran pembangunan ekonomi selanjutnya, dan (3) mendefinisikan prioritas perbaikan daya saing ekonomi lokal. Supriana dan Nasution (2010) menyatakan bahwa peran suatu kegiatan produktif masyarakat dalam PEL dapat dilihat dari kemampuannya meningkatkan pendapatan masyarakat lokal dan penyerapan tenaga kerja.
Berdasarkan latar belakang, permasalahan, dan kajian empiris di atas, tujuan penelitian ini adalah untuk menganalisis: (1) pengaruh faktor sosial ekonomi dan ekologi terhadap produktivitas kopi arabika spesialti; (2) peran komoditas kopi arabika spesialti dalam pengembangan ekonomi lokal (local economic development, LED); dan (3) aspek tata guna lahan dan dukungan kebijakan dan program pengembangan kopi arabika spesialti.

\section{METODE}

Penelitian survai usahatani kopi arabika dilakukan di wilayah dataran tinggi Kabupaten Simalungun, sementara aspek tata guna lahan dan kajian kebijakan dan program diperoleh melalui dokumen perencanaan dan wawancara dengan narasumber terpilih. Sebagian data usahatani bersumber dari survai usahatani kopi arabika yang dilakukan oleh International Finance Corporation (IFC)/World Bank Group pada tahun 2011. Data yang diambil dari IFC/WB terutama untuk seluruh usahatani kopi arabika spesialti sertifikat (di Kecamatan Sidamanik dan Pamatang Sidamanik) dengan sampel 79 rumah tangga dan sebagian data usahatani kopi arabika spesialti non-sertifikat di Kecamatan Pamatang Sidamanik, Kecamatan Dolok Pardamean, dan Kecamatan Purba (210 rumah tangga). Data usahatani kopi arabika spesialti non-sertifikat dari Kecamatan Sidamanik, Silimakuta, Pamatang Silimahuta, dan sebagian Kecamatan Purba, dilakukan survai usahatani dengan menggunakan kuesioner.

Pemilihan sampel wilayah dilakukan dengan multi-stage cluster sampling (MSCS). Penentuan klaster sampel dilakukan dengan menggunakan purposive sampling sementara penentuan sampel rumah tangga menggunakan teknik probabilityproportional-to-size (PPS) dari populasi sebesar 16.416 rumah tangga (Nazir, 2009; Sudjarwo dan Basrowi, 2009; Bungin, 2008; Sudarso, 2007; Lubis, 2002; Magnani, 1997; Mantra dan Kasto, 1995). Sementara data sekunder diperoleh dari situs ICO, Ditjen Perkebunan, BPS Sumatera Utara, , BPS Simalungun, Dinas Perkebunan Simalungun, serta publikasi resmi lainnya.

Data usahatani dianalisis dengan model regresi linier berganda (multiple linear regression, MLR) dengan uji yang gayut seperti: uji validitas dan reliabilitas, uji 
normalitas, uji multikolinearitas dan heteroskedastisitas, goodness of fit test, uji $\mathrm{t}$, dan uji F. Peran komoditas kopi arabika dalam PEL dikaji secara deskriptif (koefisien korelasi, share analysis, dan scenario analysis). Kajian tata guna lahan dianalisis secara deskriptif, sementara policy review dan dukungan program dianalisis berdasarkan pertimbangan narasumber dan need assessment.

\section{HASIL}

\section{Uji Validitas dan Reliabilitas}

Berdasarkan nilai koefisien korelasi item-total terkoreksi (corrected item-total correlation) yang lebih besar dari r-tabel, maka semua variabel penelitian yang digunakan adalah valid dan kuesioner yang digunakan dapat mengukur dengan tepat data yang diperlukan. Sementara pengujian reliabilitas menunjukkan nilai koefisien alpha Cronbach $\left(C_{\alpha}\right)$ sebesar 0,747 lebih besar dari 0,7 , yang berarti bahwa instrumen penelitian atau kuesioner yang digunakan dinyatakan memiliki reliabilitas yang memadai (Hair et al., 1998 dalam Kusnendi, 2008).

\section{Uji Asumsi Klasik}

Dalam penelitian ini digunakan pendekatan grafik (scatter plot) dan histogram untuk menguji normalitas data. Jika data menyebar di sekitar garis diagonal dan cenderung mengikuti arah garis diagonal, maka model regresi memenuhi asumsi normalitas. Metode scatter plot menunjukkan data menyebar di sekitar garis diagonal dan cenderung mengikuti arah garis diagonal. Dengan kata lain, tidak ada data yang menyebar jauh dari garis diagonal. Kesimpulan yang dapat ditarik adalah bahwa asumsi normalitas dapat dipenuhi atau data yang yang diperoleh berasal dari populasi yang berdistribusi normal.

Berdasarkan nilai tolerance dan VIF dapat disimpulkan bahwa model regresi yang digunakan bebas dari masalah multikolinearitas, sementara berdasarkan metode grafik, diagram pencar model regresi linier tidak memiliki pola yang teratur sehingga tidak ditemukan masalah heteroskedastisitas dalam model yang digunakan.

\section{Goodness of Fit Test}

Koefisien determinasi $\left(\mathrm{R}^{2}\right)$ model penelitian signifikan pada tingkat $\alpha=1 \%$, dengan nilai 0,650 . Hal ini berarti bahwa $65 \%$ variasi total dalam produktivitas kopi arabika spesialti (variabel terikat) dapat dijelaskan secara signifikan oleh semua variabel bebas yang dimasukkan ke dalam model dengan tingkat kepercayaan $99 \%$. Sisanya, sebesar $35 \%$ variasi dari produktivitas kopi arabika spesialti tersebut dijelaskan oleh variabel bebas lain yang tidak dimasukkan ke dalam model. Kesimpulan ini diambil karena $p$-value $<\alpha(0,000<$ $0,05)$. Dengan demikian, model penelitian merupakan model yang fit (sesuai) dan dapat digunakan untuk menduga koefisien regresi dan menentukan pengaruh semua variabel bebas (baik secara serempak maupun secara parsial) terhadap variabel terikat.

\section{Pengaruh Faktor Sosial Ekonomi dan Ekologi terhadap Produktivitas}

Hasil estimasi model penelitian untuk melihat pengaruh faktor sosial-ekonomi terhadap produktivitas kopi arabika spesialti dapat dilihat pada Tabel 1. Berdasarkan hasil estimasi dengan SPSS versi 17 , persamaan regresi untuk model penelitian dapat ditulis:

$$
\begin{aligned}
\hat{Y}_{k}=-2.169,789 & -10,105 X_{1}-18,663 X_{2}+1,532 X_{3} \\
& +363,912 X_{4}+0,041 X_{5} \\
& +14,069 X_{6}+3,240 X_{7}+0,011 X_{8} \\
& +0,119 X_{9}+102,272 X_{10} \\
& +339,926 X_{11}-1,243 X_{12} \\
& -2,532 X_{13}+247,764 X_{14} \\
& +36,140 X_{15}+248,882 X_{16} \\
& -401,139 S
\end{aligned}
$$

Dari 17 variabel bebas yang dimasukkan ke dalam model, terdapat sembilan variabel yang berpengaruh positif dan signifikan terhadap produktivitas kopi arabika spesialti. Variabel-variabel tersebut adalah luas lahan, jumlah tenaga kerja, modal, harga kopi, pemanfatan lahan, likuiditas petani, pemangkasan tanaman kopi, pengendalian penggerek buah kopi (PBKo), dan sertifikasi kopi (S). Sementara delapan variabel lain (pendidikan, pengalaman, peran perempuan, jumlah tanaman kopi, lama produktif, pohon pelindung, pupuk organik, dan konservasi lahan) berpengaruh tidak signifikan terhadap produktivitas kopi arabika spesialti. Variabel pendidikan, pengalaman, pohon pelindung, dan pupuk organik, koefisien regresinya bertanda negatif. 
Tabel 1. Hasil estimasi model regresi linier berganda

\begin{tabular}{|c|c|c|c|c|c|c|}
\hline Variabel/notasi & & $\begin{array}{l}\text { Koefisien } \\
\text { regresi }^{1}\end{array}$ & $\begin{array}{c}\text { Simpangan } \\
\text { baku }\end{array}$ & $\begin{array}{c}\text { t- } \\
\text { hitung }\end{array}$ & $\begin{array}{c}\text { p-value } \\
\text { (sig) }\end{array}$ & $\begin{array}{l}\text { Koefisien } \\
\text { korelasi }^{2}\end{array}$ \\
\hline Konstanta & $a$ & $-2.169,789$ & 700,695 & $-3,097$ & 0,002 & . - \\
\hline Pendidikan & $X_{I}$ & $-10,105$ & 14,434 & $-0,700$ & 0,484 & $-0,042$ \\
\hline Pengalaman & $X_{2}$ & $-18,663$ & 30,844 & $-0,605$ & 0,546 & $-0,037$ \\
\hline Peran perempuan & $X_{3}$ & 1,532 & 3,709 & 0,413 & 0,680 & 0,025 \\
\hline Luas lahan & $X_{4}$ & $363,912 * * *$ & 93,887 & 3,876 & 0,000 & $0,229 *$ \\
\hline Jumlah tanaman kopi & $X_{5}$ & 0,041 & 0,059 & 0,698 & 0,486 & 0,042 \\
\hline Lama produktif & $X_{6}$ & 14,609 & 31,481 & 0,464 & 0,643 & 0,028 \\
\hline Tenaga kerja & $X_{7}$ & $3,240^{* * *}$ & 0,444 & 7,299 & 0,000 & $0,405^{*}$ \\
\hline Modal & $X_{8}$ & $0,011^{* *}$ & 0,009 & 2,280 & 0,022 & $0,178^{*}$ \\
\hline Harga & $X_{9}$ & $0,119 * * *$ & 0,034 & 3,554 & 0,000 & $0,211^{*}$ \\
\hline Pemanfaatan lahan & $X_{10}$ & $102,272^{*}$ & 76,780 & 1,332 & 0,184 & $0,181 *$ \\
\hline Likuiditas petani & $X_{11}$ & $339,926^{* * *}$ & 98,812 & 3,440 & 0,001 & $0,205^{*}$ \\
\hline Pohon pelindung & $X_{12}$ & $-1,243$ & 1,039 & $-1,195$ & 0,233 & $-0,072$ \\
\hline Pupuk organik & $X_{13}$ & $-2,532$ & 1,463 & $-1,131$ & 0,085 & $-0,105$ \\
\hline Pemangkasan tanaman kopi & $X_{14}$ & $247,764 * * *$ & 99,291 & 2,495 & 0,013 & $0,150^{*}$ \\
\hline Konservasi lahan & $X_{15}$ & 36,140 & 69,378 & 0,521 & 0,603 & 0,032 \\
\hline Pengendalian PBKo & $X_{16}$ & $248,882^{* * *}$ & 87,628 & 2,840 & 0,005 & $0,170^{*}$ \\
\hline Sertifikasi kopi & $S$ & $-401,139 * *$ & 170,071 & $-2,359$ & 0,019 & $-0,142^{*}$ \\
\hline Jumlah sampel & $n$ & 289 & \multirow{4}{*}{\multicolumn{3}{|c|}{$\begin{array}{l}\text { t-tabel }(10 \%)=1,284 \\
\text { t-tabel }(5 \%)=1,650 \\
\text { t-tabel }(1 \%)=2,340 \\
\text { F-tabel }(1 \%, 17,271)=1,485\end{array}$}} & r-tabel $=$ \\
\hline Koefisien korelasi ganda & $R$ & 0,806 & & & & 0,095 \\
\hline Koefisien determinasi & $R^{2}$ & $0,650^{* * *}$ & & & & \\
\hline F-hitung $(16,271)$ & $F$ & $29,572 * * *$ & & & & \\
\hline
\end{tabular}

Keterangan:

$1 *, * *, * * *$ varibel bebas berpengaruh nyata terhadap produktivitas pada taraf $\alpha=10 \%, 5 \%$, dan $1 \%$

$2 *$ masing-masing variabel bebas berkorelasi signifikan dengan produktivitas pada taraf $\alpha=5 \%$

\section{PEMBAHASAN}

\section{Peran Kopi Arabika Spesialti dalam PEL}

Berdasarkan wawancara dengan narasumber kunci (pakar, ekademisi, praktisi, aktivis lingkungan, dan LSM), diperoleh kesimpulan bahwa komoditas kopi arabika spesialti sangat prospektif dan strategis dalam mencapai tujuan PEL yaitu meningkatkan pendapatan petani dan penyerapan tenaga kerja lokal. Semua narasumber berpendapat bahwa peningkatan produktivitas usahatani dan kualitas produk kopi menjadi strategi utama untuk mencapai kedua tujuan PEL tersebut (Tabel 2).

Produktivitas dan pendapatan usahatani memiliki hubungan yang positif dan signifikan pada tingkat $\alpha=1 \%$ dengan koefisien korelasi $(r)$ sebesar 0,258. Kesimpulan ini diambil karena p-value < nilai $\alpha(0,000<0,01)$. Jika produktivitas kopi arabika meningkat maka pendapatan usahatani juga meningkat secara signifikan, dan sebaliknya. Demikian juga halnya dengan produktivitas dan penyerapan tenaga kerja. Antara produktivitas dan penyerapan tenaga kerja terdapat hubungan positif dan signifikan pada tingkat $\alpha=1 \%$ dengan $r$ sebesar 0,485 (p-value $<$ nilai $\alpha[0,000<$ $0,01]$ ). Jika produktivitas kopi arabika meningkat maka penyerapan tenaga kerja lokal juga meningkat secara signifikan, dan sebaliknya.

Komoditas kopi arabika spesialti memberikan peran sebesar 3,27\%, 5,99\%, dan $13,17 \%$ berturut-turut dalam pendapatan wilayah Kabupaten Simalungun, sektor pertanian, dan subsektor perkebunan. Peran ini dihitung berdasarkan pendapatan komoditas kopi arabika di tingkat usahatani, yaitu dengan pendapatan usahatani dari penjualan kopi gabah (parchment) dan penerimaan tenaga kerja yang diupah (hired labor) pada tingkat usahatani. Sementara berdasarkan indikator penyerapan tenaga kerja, kopi arabika spesialti mampu memberikan kontribusi penyerapan tenaga kerja sebesar $8,29 \%, 6,42 \%$, dan $14,47 \%$ berturut-turut dalam penyerapan tenaga kerja total, tenaga kerja sektor pertanian, dan tenaga kerja subsektor perkebunan rakyat. 
Tabel 2. Pendapat narasumber mengenai prospek kopi arabika spesialti dalam PEL

\begin{tabular}{lccccc}
\hline \multirow{2}{*}{ Aspek } & \multicolumn{5}{c}{ Potensi dan prospek pengembangan kopi arabika spesialti } \\
\cline { 2 - 6 } & Pakar & Akademisi & Praktisi & $\begin{array}{c}\text { aktivis } \\
\text { linkungan }\end{array}$ & LSM \\
\hline (1) Produktivitas & $\checkmark$ & $\checkmark$ & $\checkmark$ & $\checkmark$ & $\checkmark$ \\
(2) Kualitas & $\checkmark$ & $\checkmark$ & $\checkmark$ & $\checkmark$ & $\checkmark$ \\
(3) Pendapatan petani & $*$ & $*$ & $*$ & $*$ & $*$ \\
(4) Penyerapan tenaga kerja & $*$ & $*$ & $*$ & $*$ & $*$ \\
\hline
\end{tabular}

Keterangan: $\checkmark$ menunjukkan (1) dan (2) prospektif untuk ditingkatkan

* kopi arabika spesialti memiliki peran positif dalam PEL

Merujuk kajian empiris Bacon et al. (2008), pengembangan komoditas kopi arabika spesialti di tingkat usahatani mampu memberikan pendapatan per kapita per hari setara dengan US $\$ 2,05$. Dengan demikian, komoditas kopi arabika dapat mengurangi tingkat kemiskinan di wilayah produksi kopi arabika di Kabupaten Simalungun (dengan menggunakan kriteria garis kemiskinan Bank Dunia yaitu US\$1 per orang per hari).

Untuk tujuan perencanaan dan model pengembangan ekonomi lokal berbasis kopi arabika spesialti, penelitian ini melakukan analisis skenario untuk variabel usahatani yang dinilai berkaitan langsung dengan peningkatan produktivitas dan pendapatan petani untuk tahun 2015 dan 2020. Dengan melihat kaitan ke depan (forward linkages), kaitan ke belakang (backward linkages), dan kaitan wilayah (regional linkages), pengembangan komoditas ini dapat meningkatkan aktivitas ekonomi wilayah.

\section{Kebijakan Tata Guna Lahan}

Berkaitan dengan pengembangan kopi arabika, analisis tata guna lahan wilayah Kabupaten Simalungun dilakukan untuk dua aspek: pola ruang dan masalah kawasan hutan pasca Kepmenhut RI 44/2005. Berdasarkan Rencana Tata Ruang Wilayah (RTRW) Kabupaten Simalungun Tahun 2011-2031, kawasan perkebunan rakyat seluas 85.768 ha, termasuk di dalamnya perkebunan rakyat kopi arabika seluas 7.067 ha (2011). Sebagai lokalitas yang unik, kawasan perkebunan kopi arabika spesialti perlu dipetakan sebagai satu kesatuan untuk memperoleh Indikasi Geografis. Untuk itu, sebagian lokasi perkebunan rakyat masuk dalam kawasan hutan pasca SK 44/2005. Karena SK 44/2005 secara langsung atau tidak langsung berdampak negatif dalam pengembangan kopi arabika spesialti di Simalungun, maka perlu segera direvisi.

\section{Dukungan Kebijakan dan Program Pemerintah Daerah}

Analisis dukungan kebijakan dan program pemerintah daerah terkait dengan pengembangan kopi arabika spesialti dilakukan dengan me-review dokumen kebijakan (RPJMD) dan (realisasi) program tahunan SKPD. Berdasarkan alur yang demikian, dapat diidentifikasi program yang telah dilakukan oleh SKPD terkait (program eksisting). Program eksisting tersebut dibandingkan dengan program yang direkomendasikan untuk memperoleh kebutuhan program. Rekomendasi program diperoleh dari beberapa dokumen yang gayut dengan produksi kopi berkelanjutan (sustainable coffee) dan pendapat narasumber.

RPJMD Kabupaten Simalungun Tahun 2011-2015 (Perda 6/2011), memuat tujuan pembangunan yang dinilai sejalan dengan strategi PEL. Salah satu tujuan pembangunan yang digariskan bertema "peningkatan kesejahteraan masyarakat melalui pengembangan aktivitas ekonomi berbasis potensi lokal". Merespon tujuan tersebut, ditetapkan sasaran pembangunan, yaitu mengurangi kemiskinan (poverty reduction) dan pengangguran (peningkatan kesempatan kerja).

Namun kebijakan tersebut belum didukung oleh program yang memadai. Untuk itu, direkomendasikan setidaknya 14 program terpilih sebagai tindaklanjut dari kebijakan dan sasaran yang telah digariskan dalam RPJMD, yaitu: (1) pengembangan model farm, (2) pelatihan usahatani terpadu, (3) peningkatan kapasitas kelompok tani dalam manajemen (bisnis) usahatani, (4) pelatihan tenaga penyuluh khusus kopi 
spesialti, (5) fasilitasi akses petani terhadap input, (6) kebun benih dan kebun bibit desa, (7) fasilitasi kredit usahatani kopi arabika spesialti (KUK), (8) revitalisasi pendataan dan pemetaan wilayah kopi arabika spesialti, (9) Standardisasi pulper dan pengolahan semi-basah, (10) Sosialisasi dan event kopi spesialti, (11) buying \& processing station, (12) research station, (13) product development untuk brand Simalungun Specialty Coffee (SSC), dan (14) peningkatan infrastruktur.

Untuk menjamin program tersebut, diperlukan penataan ulang SKPD (termasuk perusahaan daerah) --minimal menata ulang dan merevitalisasi tugas pokok dan fungsinya-- atau paling tidak melakukan tugas pokok dan fungsinya secara konsisten. Selain itu, potensi dan fasilitas yang ada (325 orang tenaga penyuluh, kebun induk dan kebun bibit, Pusat Pelatihan Petani Kopi IFC) perlu dioptimalkan. Akhirnya, keberhasilan suatu program akan lebih optimal jika dilakukan melalui kemitraan multipihak (SKPD terkait, perguruan tinggi, LSM lokal, dan pemangku kepentingan lainnya).

\section{Rekomendasi Model PEL Berbasis Kopi Arabika Spesialti}

Sejauh penelusuran penulis, kajian model pengembangan komoditas kopi masih sebatas mengintegrasikan faktor sosial ekonomi dan ekologi dengan variabel yang bervariasi. Model fungsi produksi yang dikaji secara empiris antara lain dilakukan oleh Wollni dan Brümmer (2009), Poudel et al. (2010), Poudel et al. (2011), dan Doutriaux et al. (2008). Model yang dibangun secara umum dapat digambarkan sebagai berikut (Gambar $3)$.

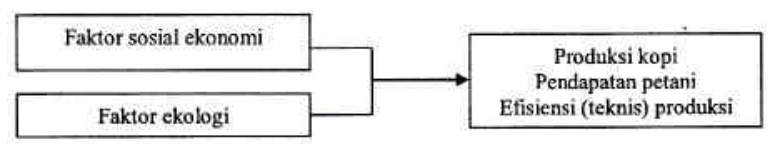

Gambar 3. Model produksi, efisiensi produksi, dan pendapatan usahatani kopi

Syahza (2003), dengan metode survai (Rapid Rural Appraisal/RRA) dan analisis deskriptif, merekomendasikan model pemberdayaan ekonomi masyarakat perdesaan berbasis agribisnis yang dapat digunakan secara umum untuk tanaman pangan, horti-kultura, perkebunan, perikanan, dan peternakan. Bappenas RI mengimplemetasikan progam Kemitraan PEL (KPEL) berbasis klaster ekonomi kopi di Kabupaten Tanggamus dan Lampung Barat dengan tujuan untuk memperkuat petani kopi dan pengolah untuk bersaing di pasar internasional (United Nations, 2005). Bogapane (2012) merekomen-dasikan model PEL secara umum yang terkait dengan empat tema untuk transformasi fungsi dan kinerja PEL di tingkat kabupaten (district) di Afrika Selatan (Gambar 4).

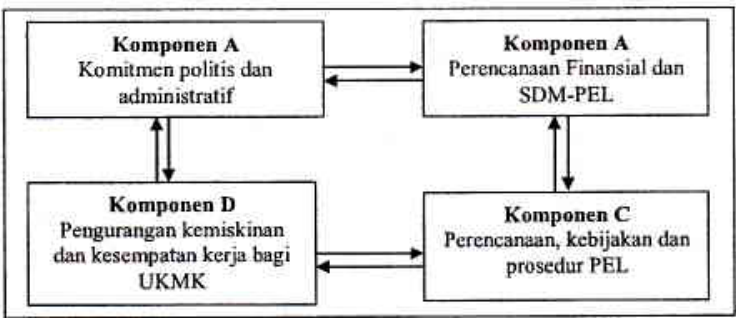

Gambar 4. Model PEL yang disarankan untuk tingkat kabupaten (Bogapane, 2012)

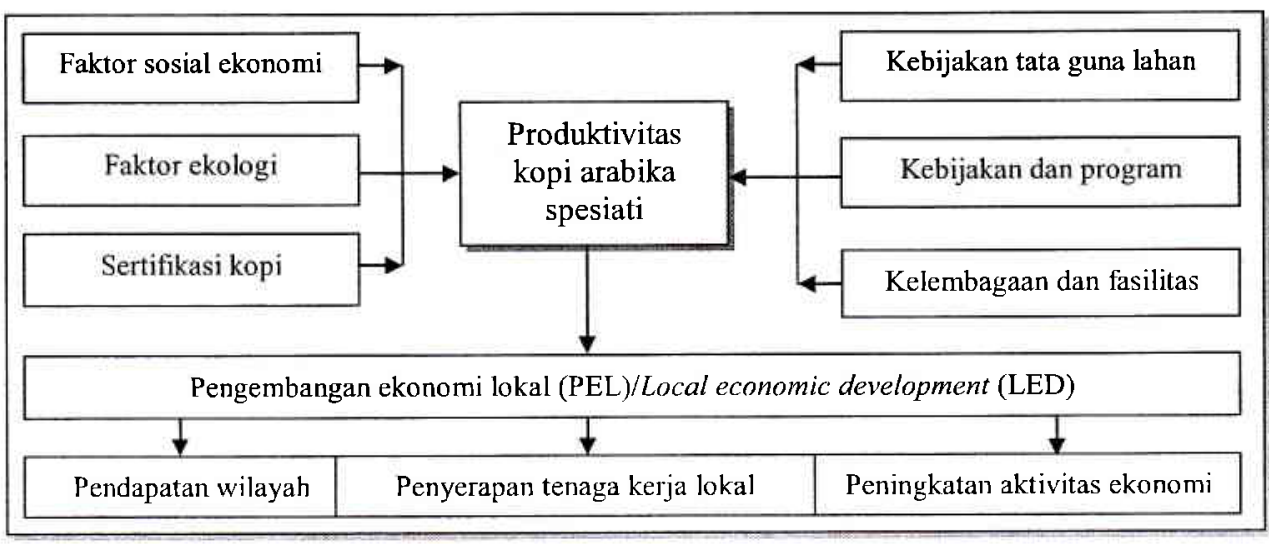

Gambar 5. Model PEL berbasis peningkatan produktivitas kopi arabika spesialti 
Penelitian ini merekomendasikan suatu model pengembangan ekonomi lokal (PEL) berbasis kopi arabika spesialti di Kabupaten Simalungun. Model ini mengacu pada hasil analisis regresi linier berganda, manfaat sertifikasi kopi, tata guna lahan, kebutuhan program, dan peran komoditas kopi arabika dalam PEL. Model dibangun oleh 6 (enam) komponen utama, yaitu: (1) komponen sosial ekonomi, (2) komponen ekologi, (3) sertifikasi kopi arabika spesialti, (4) kebijakan tataguna lahan, (5) kebijakan dan program pemerintah daerah, dan (6) kelembagaan dan fasilitas pendukung (Gambar 5).

\section{KESIMPULAN}

(1) Produktivitas kopi arabika spesialti dapat ditingkatkan melalui intervensi variabel ekonomi yang berpengaruh signifikan dan penerapan praktik-praktik pertanian yang baik (good agricultural practices, GAPs). Peningkatan produktivitas dapat dicapai dengan strategi perluasan luas kebun, optimalisasi penggunaan tenaga kerja keluarga, peningkatan biaya pupuk organik dan kimia, peningkatan harga kopi gabah, peningkatan harga premium kopi sertifikat, optimalisasi pemanfaatan lahan, peningkatan likuiditas keuangan rumah tangga petani, peningkatan praktik pemangkasan tanaman kopi, dan pengendalian penggerek buah kopi atau PBKo. Sebagai faktor akselerasi peningkatan produktivitas dan kualitas. kopi arabika spesialti diperlukan: (1) pemetaan ulang sentra produksi, termasuk revisi Kepmenhut 44/2005; dan (2) introduksi dan implementasi sejumlah program pengembangan di tingkat usahatani dan wilayah.

(2) Kopi arabika spesialti merupakan komoditas yang sangat prospektif dan strategis untuk mencapai tujuan PEL yaitu meningkatkan pendapatan petani dan penyerapan tenaga kerja lokal. Berdasarkan indikator pendapatan, komoditas ini memberikan kontribusi sebesar $3,27 \% ; \quad 5,99 \%$; dan $13,17 \%$ berturut-turut dalam pendapatan wilayah (PDRB), PDRB sektor pertanian, dan PDRB subsektor perkebunan. Berdasarkan indikator penyerapan tenaga kerja, komoditas kopi arabika spesialti mampu memberikan kontribusi penyerapan tenaga kerja sebesar $8,29 \%$; $14,47 \%$; dan $24,86 \%$, berturut-turut dalam penyerapan tenaga kerja total, penyerapan tenaga kerja sektor pertanian, dan penyerapan tenaga kerja subsektor perkebunan rakyat.

(3) Dengan menggunakan garis kemiskinan Bank Dunia (US\$1 per orang per hari), usahatani kopi arabika spesialti mampu memberikan pendapatan per kapita sebesar US $\$ 2,05$ per kapita per hari, sehingga mampu menurunkan tingkat kemiskinan (poverty reduction) $\mathrm{di}$ wilayah perdesaan.

\section{SARAN}

Pemerintah Kabupaten Simalungun agar mengadopsi model pengembangan ekonomi lokal (PEL) berbasis produktivitas kopi arabika spesialti, sebagai rekomendasi utama penelitian ini.

\section{DAFTAR RUJUKAN}

Adji, Mas Wedar. 2011. Konsep pengembangan ekonomi lokal perkotaan, makalah pada Sosialisasi Pengembangan Ekonomi Lokal Perkotaan se-Provinsi Riau, Pekan Baru, 18 Juli 2011, Badan Perencanaan Pembangunan Nasional RI. www.usdrp-indonesia.org/ files/downloadContent [diakses 5 September 2011]

Bartik, Timothy. 2003. Local economic development policy, Upjohn Institute Staff Working Paper No. 03-91.

Blakely, Edward James. 1994. Planning local economic development: theory and practice, California: SAGE Publications, Inc.

Bote, Adugna D.; and Paul C. Struik. 2011. Effects of shade on growth, production and quality of coffee (Coffea arabica) in Ethiopia, Journal of Horticulture and Forestry 3 (11): 336-341.

Chmura, Krzysztof; and Azamat Orozobekov. 2009. Decentralization and local government program in the Kyrgyz Republic, Handbook on How to Manage Local Economic Development, USAID Central Asian Republics. 
pdf.usaid.gov/pdfdocs/PDACP 757. pdf [diakses 5 September 2011]

Dinas Perkebunan Kabupaten Simalungun. 2007. Perwilayahan KIMBUN Kabupaten Simalungun, Dinas Perkebunan Kabupaten Simalungun.

Doutriaux, Sylvie; Charles Geisler, Gerald Shively. 2008. Competing for coffee space: development-induced displacement in the Central Highlands of Vietnam. Rural Sociology 73 (4): 528-554.

Ibanez, Marcela. 2010. Adoption of certified organic technologies: the case of coffee farming in Colombia, Proceedings of the German Development Economics Conference, Hannover, Conference paper No. 58, http://hdl.handle.net/10419/ 39997 [diakses 17 Maret 2012]

Ibrahim, Hadiyan Wijaya; and Suhaiza Zailani. 2010. A review on the competitiveness of global supply chain in a coffee industry in Indonesia, International Business Management 4 (3): 105-115.

ILO. 2010. Gender mainstreaming in local economic development strategies: A guide, Geneva: ILO Bureau for Gender Equality.

James, Sara-Beth; Thomas W. Ilvento, and Steven E. Hastings. 2002. The effect of local economic development policy on employment growth in rural counties in the Mid-Atlantic Region, FREC SP02-0, Newark: University of Delaware.

Joseph, Carmel. 2002. Local economic development and job creation, Occasional Paper No. 7, Friedrich Ebert Stiftung South Africa Office.

Mawardi, Surip. 2007. Promoting specialty coffee from Indonesia to be protected by Geographical Indication: A case study on Kintamani Bali Arabika, Seminar on Georaphical Indications (GIs), Phnom Penh.

Poudel, Krishna Lal; Naoyuki Yamamoto, Yasuhiro Sugimoto, Aya Nishiwaki, and Hideyuki Kano. 2010. Estimation of production function and resource use condition of organic coffee cultivation in different farm size and altitude categories in the hill region of
Nepal. European Journal of Scientific Research 45 (3): 438-449.

Poudel, Krishna Lal; Naoyuki Yamamoto, Yasuhiro Sugimoto, Aya Nishiwaki, and Hideyuki Kano. 2011. Comparing technical efficiency of organic and conventional coffee farms in Nepal using data envelopment analysis (DEA) approach. 85rd Annual Conference of the Agricultural Economics Society, Warwick University.

Rhinehart, Ric. 2009. What is specialty coffee?, Specialty Coffee Association of America (SCAA). http://www.scaa.org/?page=RicArtp2 [diakses 4 Juli 2011]

Supriana, Tavi; dan Vita Lestari Nasution. 2010. Peran usaha TKI Purna terhadap pengembangan ekonomi lokal dan faktor yang mempengaruhi pendapatan usaha TKI Purna di Provinsi Sumatera Utara. Makara Sosial Humaniora 14 (1): 42-50.

Thirtle, Colin; Xavier Irz, Lin Lin, Victoria McKenzie-Hill, and Steve Wiggins, 2001, Relationship between changes in agricultural productivity and the incidence of poverty in developing countries (Report No. 7946). London: Department for International Development (DFID).

United Nations. 2005. Rural-urban linkages for poverty reduction, a review of selected approaches from Asia and the Pacific, United Nations.

Wollni, Meike; and Bernhard Brümmer. 2009. Productive efficiency of specialty and conventional coffee farmers in Costa Rica: Accounting for technological heterogeneity and selfselection, Discussion Papers, Courant Research Centre, Georg-AugustUniversitat Gottingen.

World Bank. 2011. Making local economic development strategies: A trainer's manual,

http://www.worldbank.org/urban/loc al/toolkit/pages/defining-led.htm [diakses 28 September 2011] 